GEAP-13731

AEC Research and

Development Report

August 1971

\title{
MEASURED LOSS OF SELECTED FISSION PRODUCTS \\ FROM HIGH-BURNUP MIXED-OXIDE FUEL IN \\ A MINIATURE PUMPED SODIUM LOOP
}

D. E. Plumlee

P. E. Novak

Approved: DR. willeniof for

Principal Project Engineer
Approved:

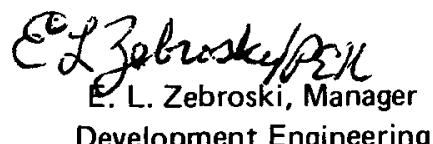

Prepared for the

United States Atomic Energy Commission

Contract AT (04-3)-189

Project Agreement 10

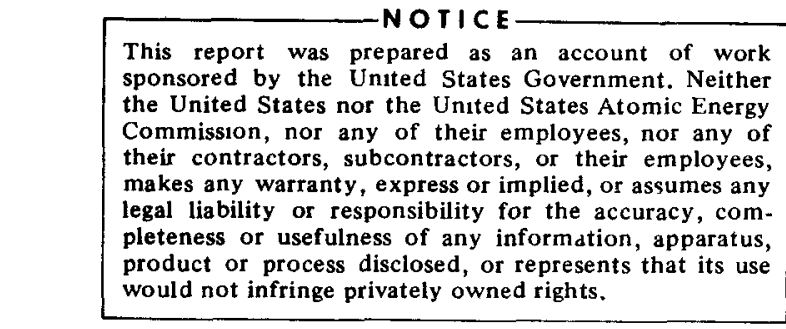

BREEDER REACTOR DEPARTMENT • GENERAL ELECTRIC COMPANY

SUNNYVALE, CALIFORNIA 94086

\section{GENERAL ELECTRIC}




\section{DISCLAIMER}

This report was prepared as an account of work sponsored by an agency of the United States Government. Neither the United States Government nor any agency Thereof, nor any of their employees, makes any warranty, express or implied, or assumes any legal liability or responsibility for the accuracy, completeness, or usefulness of any information, apparatus, product, or process disclosed, or represents that its use would not infringe privately owned rights. Reference herein to any specific commercial product, process, or service by trade name, trademark, manufacturer, or otherwise does not necessarily constitute or imply its endorsement, recommendation, or favoring by the United States Government or any agency thereof. The views and opinions of authors expressed herein do not necessarily state or reflect those of the United States Government or any agency thereof. 


\section{DISCLAIMER}

Portions of this document may be illegible in electronic image products. Images are produced from the best available original document. 


\section{NOTICE}

This report was prepared as an account of work sponsored by the United States Government. Neither the United States nor the United States Atomic Energy Commission. nor any of their employees, nor any of their contractors, subcontractors, or their employees, makes any warranty, express or implied, or assumes any legal liability or responsibility for the accuracy, completeness or usefulness of any information, apparatus, product or process disclosed, or represents that its use would not infringe privately owned rights. 


\section{TABLE OF CONTENTS}

ABSTRACT . . . . . . . . . . . . . . . . . . . . . . . . . . . . . . . . 1.1

1 INTRODUCTION . . . . . . . . . . . . . . . . . . . . . . . . . . . . . . . . . 1-1

2 SUMMARY OF RESULTS AND CONCLUSIONS . . . . . . . . . . . . . . . . . . . . 2-1

3 EXPERIMENT DESCRIPTION . . . . . . . . . . . . . . . . . . . . . . . . . . . 3

4 POST-TEST LOOP EXAMINATION . . . . . . . . . . . . . . . . . . . . . . . . . . . . . . . . . . 4-1

5 DISCUSSION . . . . . . . . . . . . . . . . . . . . . . . . . . . . . . . . 5-1

51 Test Sample $\quad 51$

52 Fission Product Deposition in the Loop $\quad 51$

ACKNOWLEDGMENTS . . . . . . . . . . . . . . . . . . . . . . . . . . . . R-1

REFERENCES . . . . . . . . . . . . . . . . . . . . . . . . . . . . . . . R-1

APPENDIX EXPERIMENT DESCRIPTION . . . . . . . . . . . . . . . . . . . . . . . . . A-1

DISTRIBUTION . . . . . . . . . . . . . . . . . . . . . . . . . . . 1 
○

• 


\section{LIST OF ILLUSTRATIONS}

Figure

Title

31 A Schematıc Diagram of Sodıum Loop

3 1B Photograph of Sodıum Loop in Hot Cell

41 Post Test Neutron Radıograph of Test Sample

42 Relative Activity in Loop

43 Key to Loop Sectıonıng and Samplıng

51 Pre and Post Test Claddıng Diameter Measurements of Test Sample

52 Post Test Appearance of Test Sample

A 1 Loop Containment Box

A 2 Positıonıng of Getterıng Cartrıdge and Fuel Sample Durıng Sodıum Purificatıon and Test

\section{LIST OF TABLES}


-

• 


\begin{abstract}
A defected section of mixed-oxide fuel preirradiated to $\sim 41,000 \mathrm{MWd} / \mathrm{Te}$ was exposed to $\sim 1150^{\circ} \mathrm{F}$ flowing sodium for 18 hours in a miniature pumped loop in a hot cell. Fuel pin diametral increase and the transfer of fuel and fission product species from the fuel specimen to different portions of the loop were measured, to provide an improved design basis for the accommodation of failed fuel in LMFBR systems. Post-test examination of the fuel specimen showed: (1) an 3\% increase in the average diameter of the fuel section, (2) less than $1 \%$ loss of fuel from the specimen with uranium preferentially leached compared with plutonium, and (3) substantial loss of fuel specimen fission products ranging from 29 to $85 \%$ for the isotopes investigated. Post-test examination of the loop indicated plate-out of fission products in the colder regions, with the exception of $C_{s}$ which remained in solution in the sodium.
\end{abstract}

\title{
1. INTRODUCTION
}

The successful development of liquid-metal-cooled fast breeder reactors (LMFBR's) requires that the reactor operate for extended periods of time with failed fuel pins in the core. Knowledge of the amounts and the species of fission products released from failed fuel pins and the subsequent deposition of these fission products throughout the primary system must be obtained to provide a basis for designing reactors for safe operation, habitation by operating personnel, and economic maintenance.

Loss of fuel and fission products from failed elements to the primary coolant can occur both during irradiation with the elements at power, and during reactor shutdown.

To provide some information on possible fuel and fission product release from failed elements during reactor shutdown, a small pumped sodium loop was fabricated, and a section of preirradiated mixed-oxide fuel was tested to determine the extent of fuel and fission product loss and the increase in diameter resulting from fuel-sodium reaction. This report describes the results of the test. 
0

0 


\section{SUMMARY OF RESULTS AND CONCLUSIONS}

Results of this 18-hour test in a miniature sodium loop indicate the following facts

a Significant fission product losses can occur in a relatively short time period. The measured loss of selected fission products from the fuel of the test sample to the loop coolant was

$\begin{array}{lc}\text { Isotope } & \begin{array}{c}\text { Percent } \\ \text { Loss }\end{array} \\ \text { Cs } 137 & 66 \\ \text { Ce-144 } & 32 \\ \text { Ru-106 } & 85 \\ \text { Sr-90 } & 29 \\ \text { Pm-147 } & 32\end{array}$

b Less than $1 \%$ erosion or loss of fuel from the test sample occurred for local sodium velocities of up to $7 \mathrm{ft} / \mathrm{sec}$

c An average diametral increase of $3 \%$ was measured for the test sample, indicating sodium-fuel reaction occurred during the test.

d Essentially no plate-out of cesium occurred in the loop Other fission products monitored showed a deposition pattern of increased plate-out in colder regions in the loop.

e The ratio of uranium to plutonium atoms deposited in the different regions of the loop indicate that uranium was preferentially removed from the fuel

$f \quad$ The experimental methods appear promisıng for investigatıng the transport of fuel and fission product species in pumped sodium loops 
0

0 


\section{EXPERIMENT DESCRIPTION}

The experiment consisted of exposing a defected mixed-oxide fuel pin section, which had been preirradiated to $\sim 41,000 \mathrm{MWd} / \mathrm{Te}$ as a part of fuel pin $\mathrm{F} 2 \mathrm{U}^{1}$, to flowing sodium in a miniature pumped sodium loop. A schematic diagram of the loop is shown in Figure 3-1(a). A photo of the loop is shown in Figure 3-1(b).

The loop was filled with sodium and operated for 20 hours prior to inserting the fuel section in the specimen chamber. During this period, oxygen was gettered from the sodium by flowing the sodium through a cartridge of zirconium chips placed in the specimen chamber. At the end of the 20 -hour period, the zirconium getter cartridge was removed and the fuel section was placed in the specimen chamber. The loop was operated for 18 hours with the fuel specimen in place. Sodium flow within the loop was then observed to cease, and the test was terminated.

Tables 3-1 and 3-2 list the fuel and loop operating parameters. A detailed description of the loop, test sample, and loop operation is given in the Appendix.

Table 3-1

\section{TEST SAMPLE PARAMETERS}

Fuel (Pre-irradiation)

$$
\begin{aligned}
& \mathrm{Pu} /(\mathrm{Pu}+\mathrm{U}) \\
& \mathrm{U}-235 /(\mathrm{U}-235+\mathrm{U}-238)
\end{aligned}
$$

Stoichiometry

Density (\% T.D.)

Diametral Gap (in.)

\section{Cladding}

Material

Nominal Inside Diameter (in.)

Cladding Wall Thickness (in.)

\section{Defect}

Average Width (mils)

18

Average Length (in.)
Table 3-2 LOOP OPERATING PARAMETERS
Maximum Sodium Temperature

Sodium Temperature at Test Sample

Loop $\Delta T$

Sodium Flow

Weight of Sodium in Loop

Oxygen Content of Sodium (Estimated)

Velocity of Sodium Past Defect Slot

Elapsed Test Time $\sim 1260^{\circ} \mathrm{F}$

$\sim 1145^{\circ} \mathrm{F}$

$700^{\circ} \mathrm{F}$

$0.1 \mathrm{gpm}$

$860 \mathrm{gm}$

Initial $20 \mathrm{ppm}$

Final 220 ppm

1.5 to $7 \mathrm{ft} / \mathrm{sec}$

18 hours 


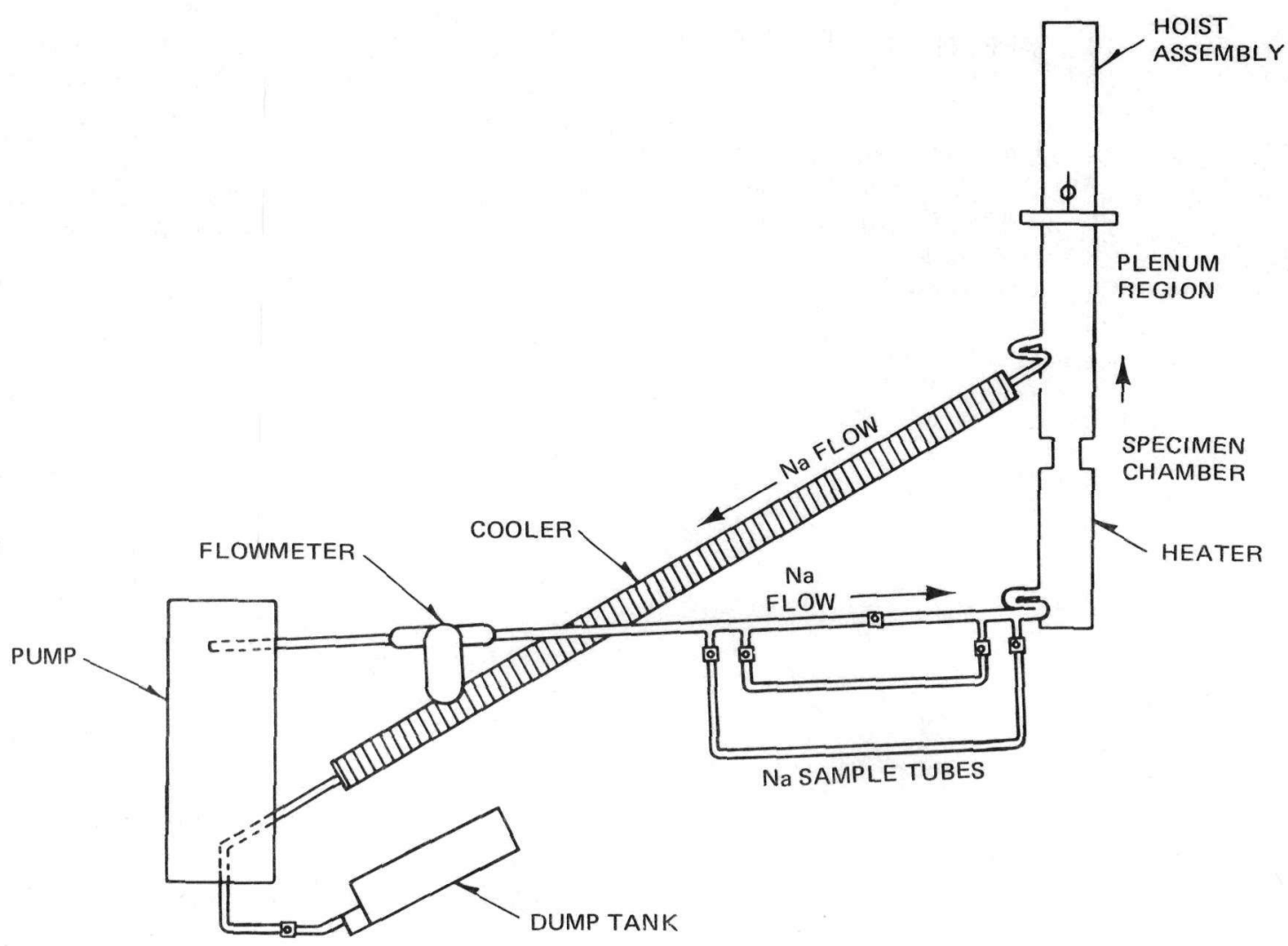

Figure 3-1A. Schematic Diagram of Sodium Loop

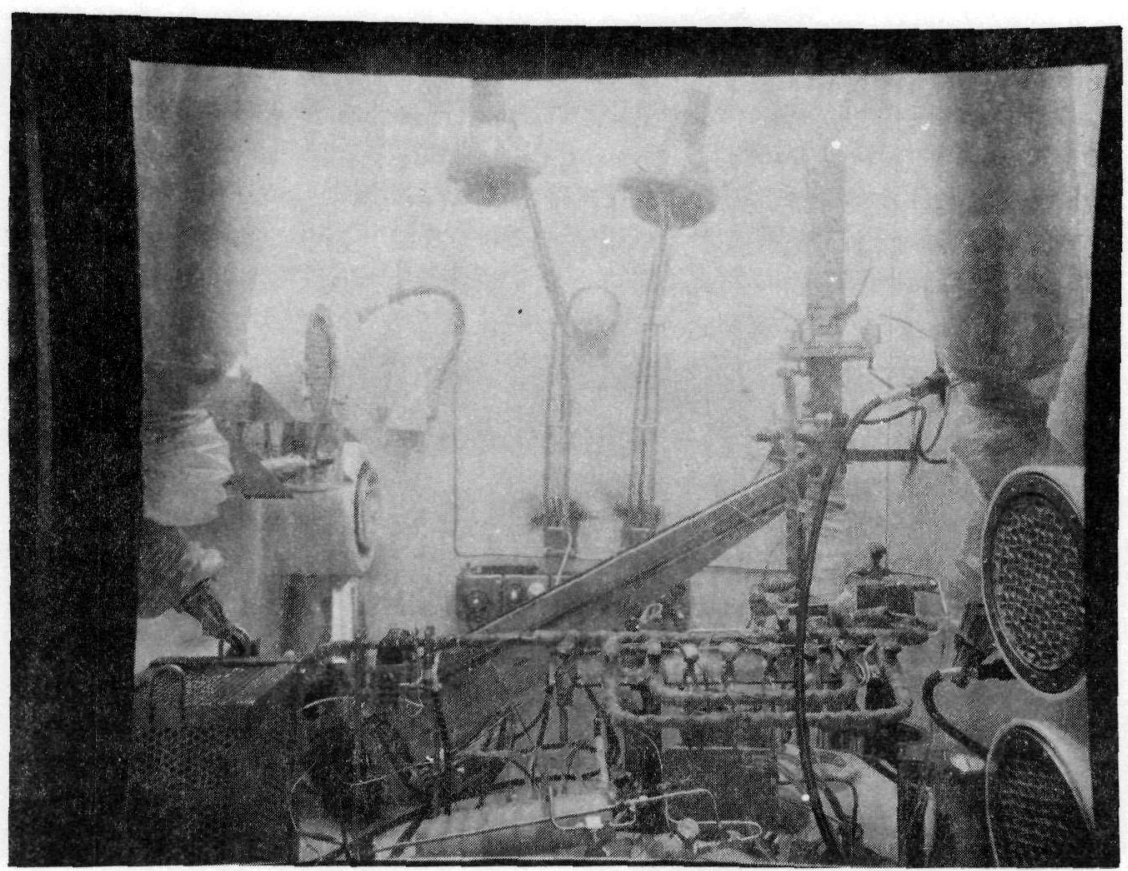

Figure 3-1B. Photograph of Sodium Loop in Hot Cell 


\section{POST-TEST LOOP EXAMINATION}

Upon termination of the test, the test sample was removed and the loop was disassembled for examination. Examination of the test sample consisted of: (1) neutron radiography, (2) post-test dimensional measurements, (3) sectioning and macroscopic examination for evidence of fuel loss, and (4) chemical analysis of test sample and control sample for selected fission products.

Figure 4-1 shows a neutron radiograph of the test sample. The view is 90 deg to the defect slot machined in the cladding. No loss of fuel could be distinguished. Some fuel or fuel-sodium reaction product was observed in the slot in the cladding.

After removing the fuel section from the specimen chamber and draining the sodium from the loop (but prior to disassembly of the loop), the gross radioactivity in the loop was measured using a shielded dose rate meter probe. The measured activity in various regions of the loop after the test is shown in Figure 4-2.

The highest activity occurred in the heater of the sample exposure section. During disassembly, however, it was found that this portion of the loop had not drained. Examination subsequent to removal of sodium from the heater showed that it did not contain a significantly greater amount of activity than other sections of the loop, indicating that the fission products in the sodium were the cause of the high activity originally detected.

Examination of the loop components consisted of leaching the inner surfaces with nitric and hydrochloric acids. The sections of the loop selected for analysis are shown in Figure 4-3. Gamma pulse height analysis was used to determine the character of the fission products present in the solutions. Separate analyses for beta emitters such as Pm-147 and Sr-90 were made, using solvent extraction methods followed by beta counting by liquid scintillation. Uranium and plutonium were separated from the sodium and fission products present in the samples by ion exchange methods. Plutonium was determined by alpha counting, and uranium by mass spectrometry, using a known U-233 spike.

Of the fission products analyzed, Cs-137 comprised more than $90 \%$ of the total atoms detected. Of the isotopes dissolved in the sodium, Cs-137 accounted for more than $99.9 \%$ of the total. 


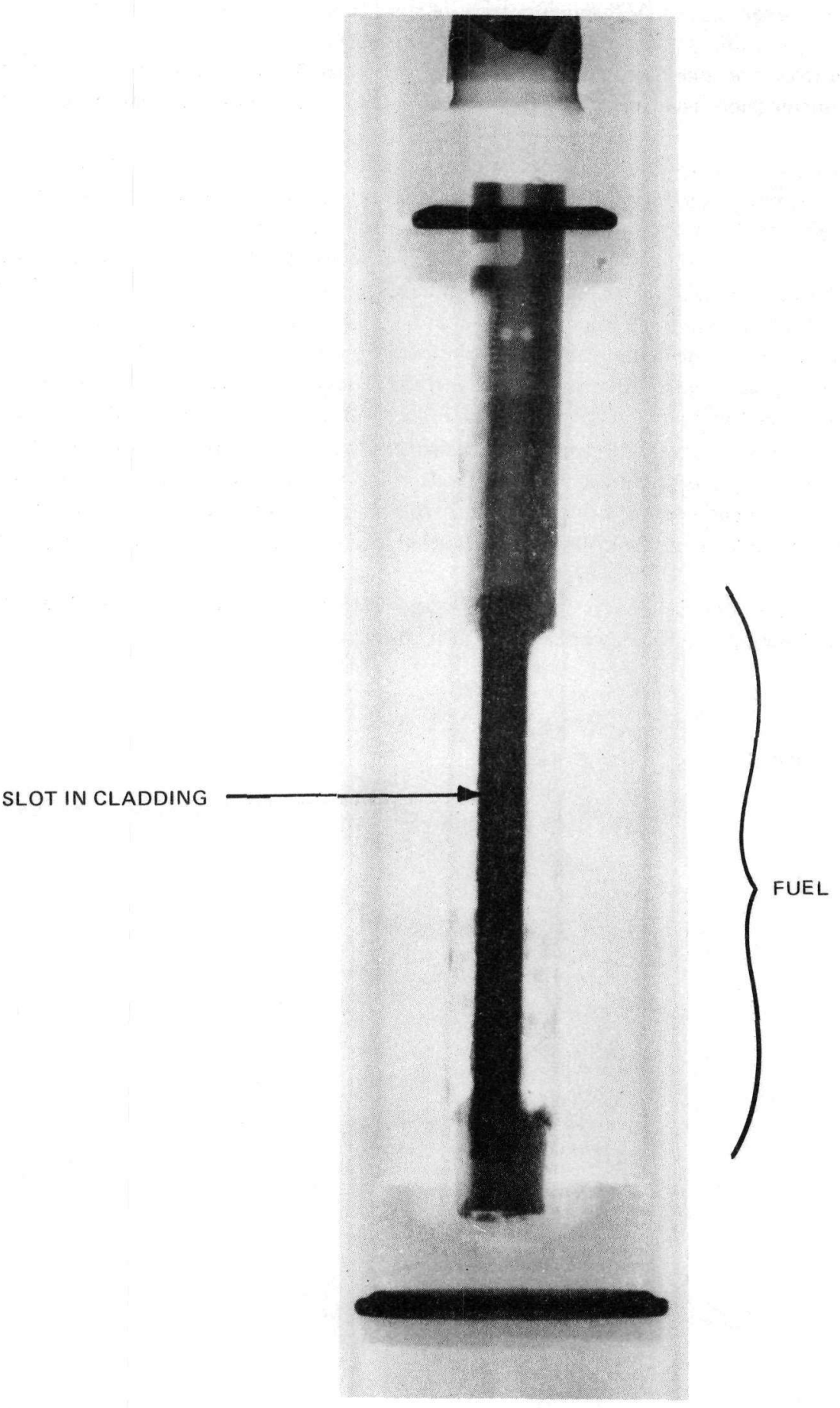

Figure 4-1. Post-Test Neutron Radiograph of Test Sample 


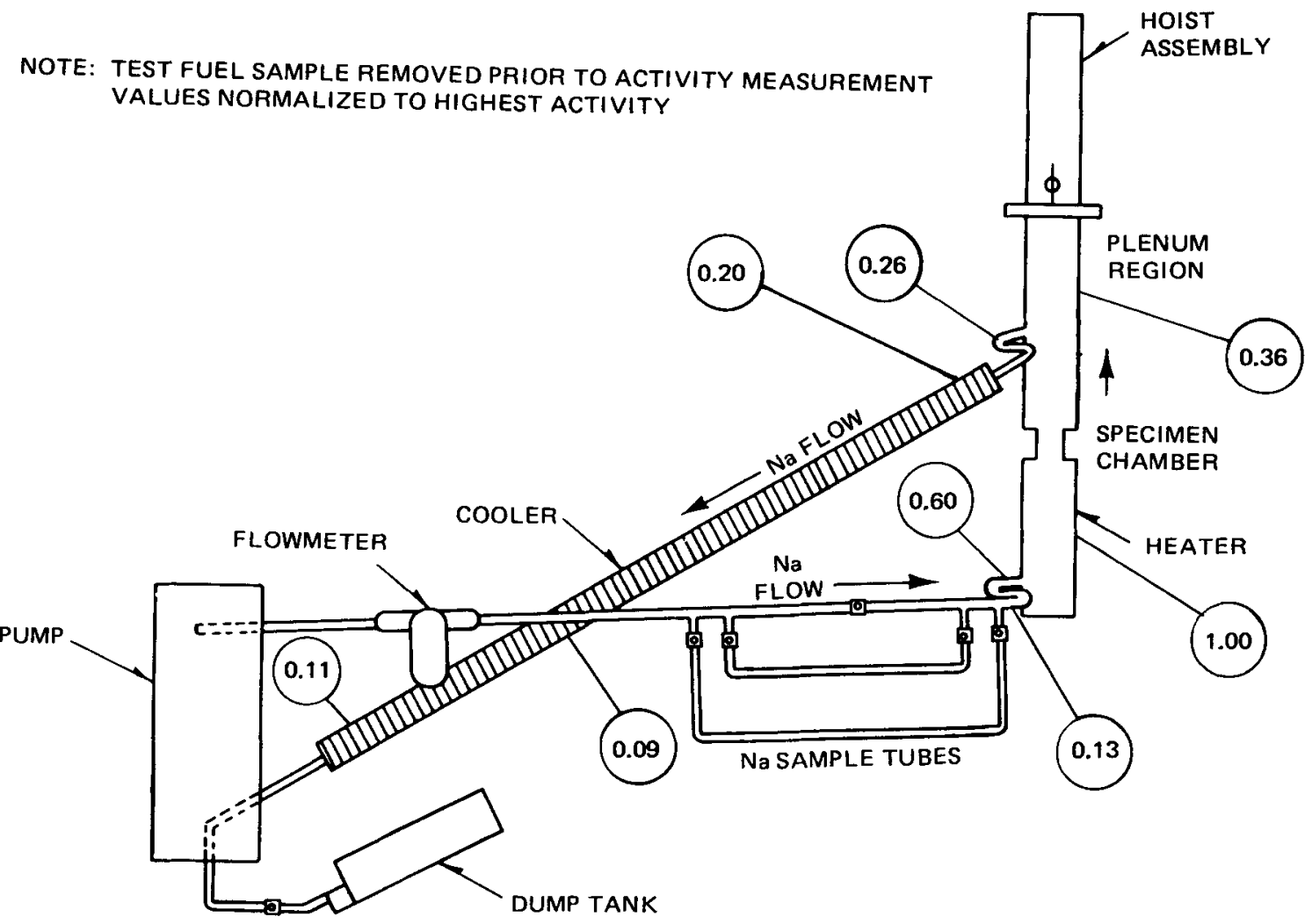

Figure 4-2. Relative Activity in Loop

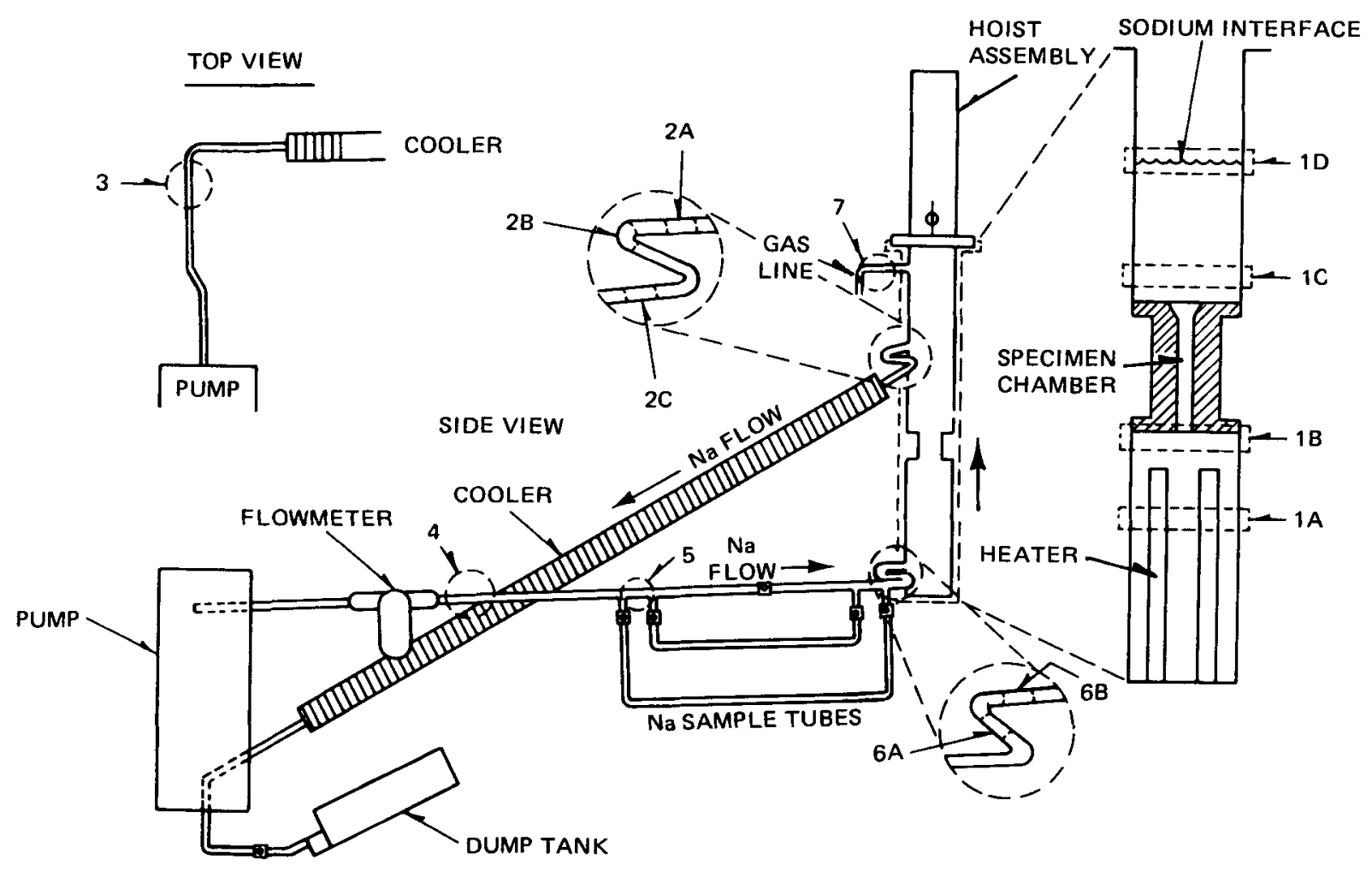

Figure 4-3. Key to Loop Sectioning and Sampling 
•

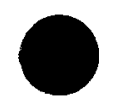




\section{DISCUSSION}

\section{TEST SAMPLE}

\subsubsection{Fuel Loss}

Figure 51 shows the pre and post test cladding diameter measurements of the test sample The greatest diametral Increases occurred at $90 \mathrm{deg}$ to the defect slot in the cladding The average cladding diameter increase was $3 \%$ These data indicate that reaction occurred between the fuel and the sodium during the test

The measured diametral increase closely agrees with that predicted from previous experımental data ${ }^{2,3}$ where the oxygen content of the sodium was greater than that required to cause reduction of the fuel sodium reaction product, 70 to $130 \mathrm{ppm}^{4}$ Accounting for the oxygen initially in the sodium, the oxygen adsorbed on the surfaces of the loop. and the oxygen in the fuel section, it is estimated that the maximum amount of oxygen that could have been in the sodium in the loop was $\sim 220 \mathrm{ppm}$ In an operatıng reactor where the oxygen content of the sodium will be maıntaıned at a low value $(<10 \mathrm{ppm})$, the extent of the fuel sodium reaction and the resultıng increase in fuel pin diameter would be expected to be less than that which occurred in this test

The post test profile of the fuel section diameter shown in Figure 51 shows that very little increase in diameter occurred in the region where the sodium flow was directed at the fuel from the nozzle (see Figure 52 ) It is hypothesized that the diameter change was decreased in this region as a result of the sodium fuel reaction product's being removed by the sodium stream as it was formed Examination after the test showed that there was very little fuel sodium reaction product present in this region of the fuel section

Although a quantitative value cannot be placed upon the amount of fuel lost, an upper lımit estımate based on metallographic examination of the fuel indicated that no more than $1 \%$ of the fuel was lost Leach analyses of the loop sections confirmed this obseivation as only minor amounts of fuel were found deposited throughout the loop

\subsection{Fission Product Loss from the Fuel}

Table 51 shows the post test analysis of the test sample for selected fission products These fission products are assumed to be representative of the remain ng fission products in the sample Also shown in Table 51 dre values determined from a control sample taken immediately adjacent to the test sample Comparison of the two analyses shows that a significant portion of the total inventory of each fission product isotope was lost during the 18 hours of loop operation Column 4 in Table 51 shows the percent loss measured for each isotope

Comparison of the present data was made with a failed fuel pın which operated for 80 to $85 \%$ of its irradiation in the falled condition to a burnup of $53,000 \mathrm{MWd} / \mathrm{Te}^{\text {s }}$ That fuel pin was contained in a capsule which permitted $\mathrm{NaK}$ to circulate past the fuel pın at velocities of 05 to $075 \mathrm{ft} / \mathrm{sec}$ Subsequent examination of the fuel pin showed multiple cracks along the length of the pin so that intımate contact probably occurred between the NaK and the fuel Durıng reactor shutdown, no flow of NaK past the pin occurred

About $15 \%$ of the cesium produced in the fuel of the pin was found to be dissolved in the NaK This value is significantly smaller than the $66 \%$ measured in the present test These data indicate that high release rates such as those measured in the present test do not occur unless sufficient coolant flow and liquid metal accessibility to the fuel is present

The foregoing data show that fission product losses can be very significant when sodium coolant is free to penetrate throughout the fuel, as can occur in failed elements during reactor shutdown Thus, to obtain true fission product release values, the exposure of the falled element to the flowing sodium both during the reactor shutdowns and during power operation must be considered

\subsection{FISSION PRODUCT DEPOSITION IN THE LOOP}

The fission products lost from the fuel were found both in the bulk sodium and in deposits on the loop walls Shown in Table 52 are the concentrations of fission products found in the bulk sodium, and these values are compared with the fission products lost from the fuel Note that only cesium dissolved in the sodium in any appreciable quantity This is in agreement with observations by the Russians in the BR 5 reactor ${ }^{6}$

Table 53 shows the total amount of fuel and fission products contained in the residual sodium and plated out on the loop walls in the various sample locations shown in Figure 43 To separate the actual amount of fission products deposited on the loop walls from the gross amount reported in Table 53 , the fission product activity in the residual sodium must be subtracted Two methods for estımatıng this activity were employed, and the results are given in Table 54 For samples 1A, 1B, 1C, 1D, and 4, actual sodium masses in the samples were measured and then multiplied 
by the fission product concentration values in Table 5-2 to yield the total fission product atoms in the sodium Withın the accuracy of the techniques $(\sim 2 X)$, the results provided further evidence that the predominant Cs activity remained in the sodium (see Tables 5-3 and 5-4) Because of this, the measured Cs-137 activities on the remaıning samples (2A, $2 B, 2 C, 3,5,6 A, 6 B, 7)$ were used to indicate the residual sodium mass present in the samples instead of by direct measurement Again applyıng the data of Table 5-2, fission product activity in the bulk sodium was computed

Subtracting the fission product species in the sodium only (Table 5-4) from the species in the sodium, plus those plated out on the loop walls (Table 5-3), yields the plate-out on the loop walls This is shown in Table 5-5

Note from the foregoing deposition data that plate-out occurs on the cooler surfaces of the loop, with the greatest plate-out occurring at the start of the downward temperature gradient, i.e, samples $2 \mathrm{~A}, 2 \mathrm{~B}$, and $2 \mathrm{C}$ (see Figure $A-5$ in Appendix for temperature distributions around the loop) This is in general agreement with the tracer level work of Brehm, et al., ${ }^{7}$ and also follows the pattern of corrosion product deposition observed by Rowland, et al ${ }^{8}$

Application of these observations to LMFBR plant design suggests that fission products will concentrate in the primary system cold trap and in the cooler portions of the intermediate heat exchanger Adequate provision for shieldıng and/or effective contamınation procedures should be developed as part of the overall maıntenance plan for these components

The initial uranium-to plutonium ratıo of the fuel was 4 to 1 However, the ratio of uranıum to plutonium found in the leach samples throughout the loop varied from 1643 to $\sim 42$ to 1 These data suggest uranium was preferentially leached from the fuel compared to plutonium It is important to recall that less than $1 \%$ of the fuel was lost from the test specimen However, these data suggest the possibility that, over long periods of time, the local enrichment of failed fuel pins may vary Further development work is required in this area. 


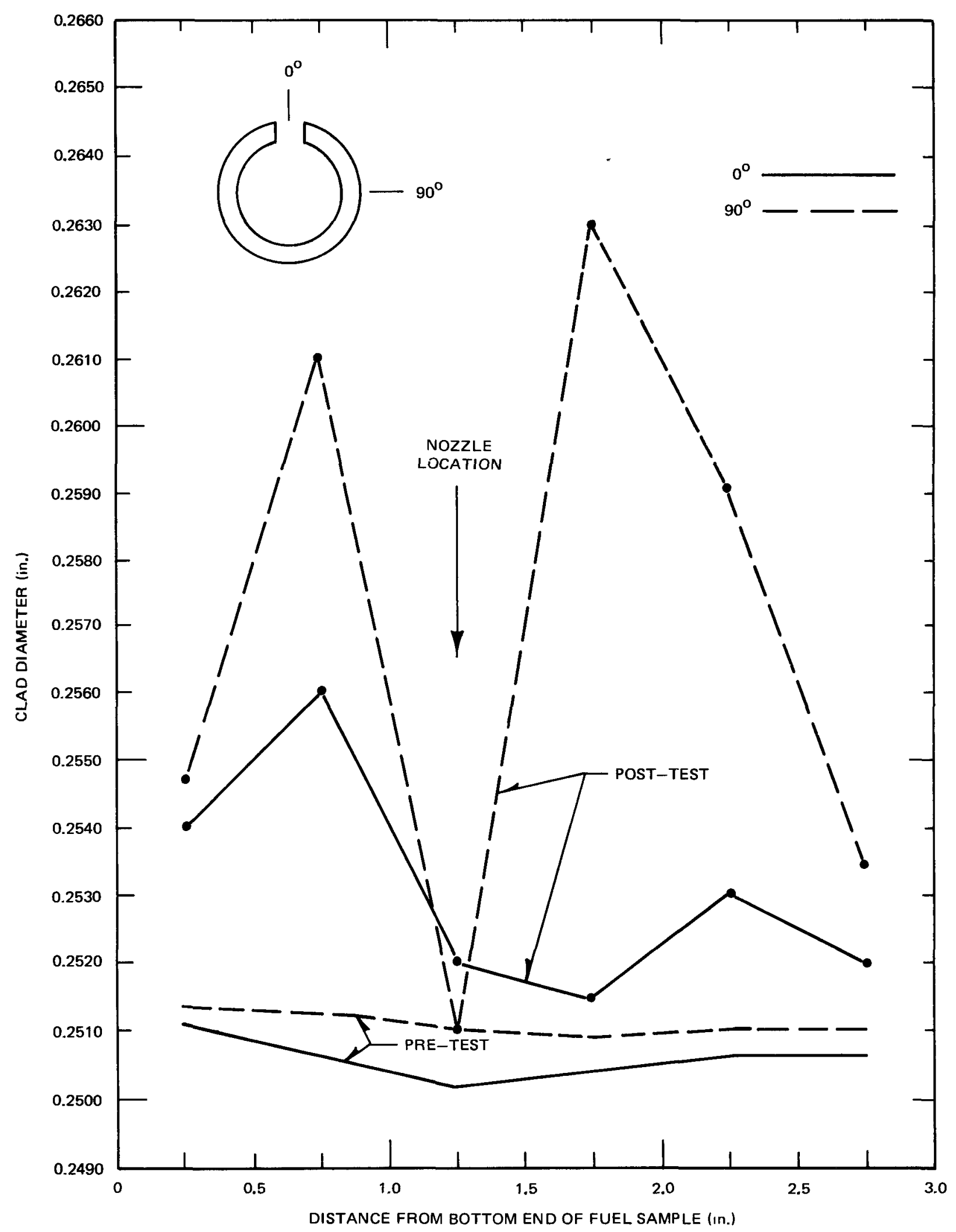

Figure 5-1. Pre-and Post-Test Cladding Diameter Measurements of Test Sample 


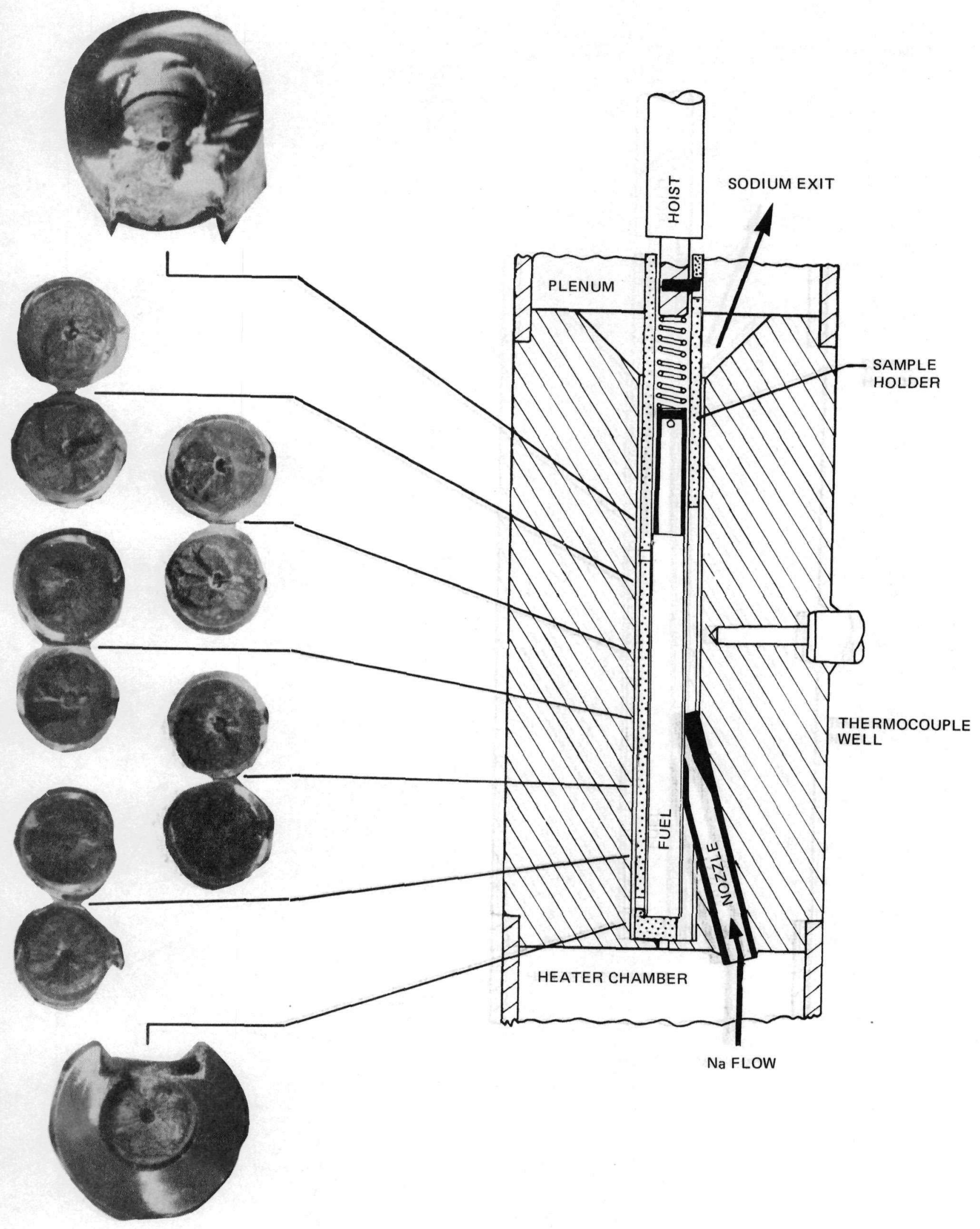

Figure 5-2. Post-Test Appearance of Test Sample 
Table 5-1

FISSION PRODUCTS IN TEST AND CONTROL SAMPLES

ATOMS/ATOM U + Pu

$\begin{array}{lccc}\text { Isotope } & \begin{array}{c}\text { Test Sample } \\ \text { After Exposure } \\ \text { to Loop }\end{array} & \text { Control Sample } & \begin{array}{c}\text { Percent } \\ \text { Loss from } \\ \text { Test Sample (a) }\end{array} \\ \text { Cs-137 } & 9.5 \times 10^{-4} & 2.4 \times 10^{-3} & 66 \\ \text { Ce-144 } & 4.0 \times 10^{-5} & 5.1 \times 10^{-5} & 32 \\ \text { Ru-106 } & 9.8 \times 10^{-6} & 5.5 \times 10^{-5} & 85 \\ \text { Zr-95 } & <3.0 \times 10^{-7} & <3.0 \times 10^{-7} & 0 \\ \text { Sr-90 } & 9.2 \times 10^{-4} & 1.1 \times 10^{-3} & 29 \\ \text { Pm-147 } & 1.3 \times 10^{-4} & 1.6 \times 10^{-4} & 32\end{array}$

(a) Based on the gamma scan of the fuel pin, the ratio of activity in the test sample to that in the control sample was 1.16 to 1 , respectively. Control sample values were then normalized to the test sample values and the percenl loss was computed.

Table 5-2

RETENTION OF FISSION PRODUCTS IN SODIUM

\begin{tabular}{|c|c|c|c|c|}
\hline Specie & $\begin{array}{l}\text { Concentration } \\
\text { (atoms/gm Na) }\end{array}$ & $\begin{array}{l}\text { Total Atoms } \\
\text { in Sodium } \\
\text { (atoms) }\end{array}$ & $\begin{array}{l}\text { Total Atoms } \\
\text { Lost from Fuel } \\
\text { (atoms) }\end{array}$ & $\begin{array}{c}\text { Retention } \\
\text { in Sodium } \\
(\%)\end{array}$ \\
\hline Cs-137 & $2.7 \times 10^{16}$ & $2.3 \times 10^{19}$ & $4.6 \times 10^{19}$ & 50 \\
\hline Sb-125 & $6.6 \times 10^{13}$ & $5.6 \times 10^{16}$ & (a) & \\
\hline Cs-134 & $5.1 \times 10^{13}$ & $4.3 \times 10^{16}$ & (a) & \\
\hline Pm-147 & $2.5 \times 10^{13}$ & $2.2 \times 10^{16}$ & $6.5 \times 10^{18}$ & 0.34 \\
\hline Sr -90 & $1.4 \times 10^{13}$ & $1.2 \times 10^{16}$ & $5.0 \times 10^{19}$ & 0.024 \\
\hline Ru-106 & $<1.3 \times 10^{11}$ & $<1.1 \times 10^{14}$ & $4.7 \times 10^{17}$ & $<0.023$ \\
\hline Ce-144 & $<5.2 \times 10^{10}$ & $<4.5 \times 10^{13}$ & $1.9 \times 10^{18}$ & $<0.0024$ \\
\hline Zr-95 & $7.3 \times 10^{9}$ & $6.2 \times 10^{12}$ & (a) & \\
\hline $\mathrm{Nb}-95$ & $3.4 \times 10^{9}$ & $2.9 \times 10^{12}$ & (a) & \\
\hline Total U & $6.6 \times 10^{15}$ & $5.6 \times 10^{18}$ & (a) & \\
\hline Total $\mathrm{Pu}$ & $1.4 \times 10^{13}$ & $1.2 \times 10^{16}$ & (a) & \\
\hline
\end{tabular}

(a) Below limits of detection 
Table 5-3

TOTAL ATOMS FROM LOOP SAMPLES

Sample Number (a)

\begin{tabular}{|c|c|c|c|c|c|c|}
\hline Isotope & $1 \mathrm{~A}$ & 1B & $1 \mathrm{C}$ & 1D & $2 A$ & $2 B$ \\
\hline Total U & $7.1 \times 10^{16}$ & $1.9 \times 10^{17}$ & $1.6 \times 10^{17}$ & $2 \times 10^{16}$ & $9.2 \times 10^{18}$ & $1.2 \times 10^{18}$ \\
\hline Total Pu & $3.9 \times 10^{15}$ & $1.3 \times 10^{16}$ & $4.6 \times 10^{15}$ & $6.2 \times 10^{15}$ & $5.6 \times 10^{15}$ & $6.0 \times 10^{15}$ \\
\hline Sb-125 & $4.8 \times 10^{14}$ & $3.2 \times 10^{15}$ & $1.4 \times 10^{14}$ & $1.3 \times 10^{14}$ & - & \\
\hline Cs-137 & $2.2 \times 10^{17}$ & $7.9 \times 10^{17}$ & $3.5 \times 10^{16}$ & $2.5 \times 10^{16}$ & $2.0 \times 10^{15}$ & $4.6 \times 10^{14}$ \\
\hline Cs-134 & $1.6 \times 10^{14}$ & $6.1 \times 10^{14}$ & $3.5 \times 10^{13}$ & $2.7 \times 10^{13}$ & - & - \\
\hline Cs-144 & $1.6 \times 10^{13}$ & $1.6 \times 10^{13}$ & $6.3 \times 10^{13}$ & $4.2 \times 10^{13}$ & $1.7 \times 10^{13}$ & $1.9 \times 10^{13}$ \\
\hline$Z r-95$ & $1.7 \times 10^{12}$ & $2.7 \times 10^{11}$ & $2.1 \times 10^{12}$ & $2.6 \times 10^{12}$ & $2.3 \times 10^{12}$ & $2.2 \times 10^{12}$ \\
\hline $\mathrm{Nb}-95$ & $1.1 \times 10^{12}$ & $3.2 \times 10^{11}$ & $2.0 \times 10^{12}$ & $1.4 \times 10^{12}$ & - & - \\
\hline$R u-106$ & $8.7 \times 10^{12}$ & $1.0 \times 10^{13}$ & $3.6 \times 10^{14}$ & $2.9 \times 10^{13}$ & $3.3 \times 10^{13}$ & $2.9 \times 10^{13}$ \\
\hline Pm-147 & $2.3 \times 10^{14}$ & $3.2 \times 10^{14}$ & $5.3 \times 10^{14}$ & $8.5 \times 10^{14}$ & $5.8 \times 10^{13}$ & $8.5 \times 10^{13}$ \\
\hline Sr-90 & $2.6 \times 10^{14}$ & $5.9 \times 10^{14}$ & $9.1 \times 10^{14}$ & $1.2 \times 10^{15}$ & $3.2 \times 10^{14}$ & $2.7 \times 10^{14}$ \\
\hline
\end{tabular}

(a) Sample location shown in Figure 4-3

ND = Not Detected 
Table 5-3 (Continued)

2C

$\begin{array}{llr}2.6 \times 10^{17} & 1.7 \times 10^{17} & <2.1 \times 10^{16} \\ 2.0 \times 10^{15} & 3.5 \times 10^{14} & 2.6 \times 10^{14}\end{array}$

$7.1 \times 10^{15} \quad 2.2 \times 10^{16}$

$1.9 \times 10^{13}$

$2.8 \times 10^{12}$

$1.6 \times 10^{12}$

$1.3 \times 10^{11}$

$1.6 \times 10^{13} \cdot 8.4 \times 10^{11}$

$6.4 \times 10^{13}$

$2.2 \times 10^{14}$
$9.9 \times 10^{12}$

$3.5 \times 10^{13}$
$1.1 \times 10^{16}$

$6.6 \times 10^{12}$

ND

$9.5 \times 10^{12}$

$2.0 \times 10^{14}$
$5.8 \times 10^{11}$
Sample Number (a)

5

6A

6B

7

$1.3 \times 10^{17}<2.1 \times 10^{16}<2.0 \times 10^{16}<2.0 \times 10^{16}$

$4.4 \times 10^{13}$

$5.2 \times 10^{12}$

$4.5 \times 10^{14}$

$9.2 \times 10^{14}$

$2.3 \times 10^{16}$

$2.4 \times 10^{16}$

$2.1 \times 10^{15}$

$7.3 \times 10^{13}$

ND

ND

$8.4 \times 10^{12}$

$2.4 \times 10^{12}$

ND

ND

$6.2 \times 10^{11}$

$1.2 \times 10^{11}$

ND

ND

$5.2 \times 10^{12}$

$2.2 \times 10^{12}$

$7.1 \times 10^{12}$

$4 \times 10^{12}$

$2.1 \times 10^{13}$

$4.3 \times 10^{12}$

$1.3 \times 10^{13}$

$7.4 \times 10^{13}$

$2.5 \times 10^{13}$ 
Table 5-4

TOTAL ATOMS RETAINED IN BULK SODIUM PORTION OF SAMPLES

\begin{tabular}{|c|c|c|c|c|c|c|}
\hline \multirow[b]{2}{*}{ Isotope } & \multicolumn{6}{|c|}{ Sample Number(a) } \\
\hline & $1 \mathrm{~A}$ & 1B & 1C & 1D & $2 A$ & 2B \\
\hline Total U & $8.7 \times 10^{16}$ & $1.5 \times 10^{17}$ & $1.5 \times 10^{16}$ & $2.6 \times 10^{15}$ & $4.9 \times 10^{14}$ & $1.1 \times 10^{14}$ \\
\hline Total Pu & $1.8 \times 10^{14}$ & $3.1 \times 10^{14}$ & $3.2 \times 10^{13}$ & $5.6 \times 10^{12}$ & $1.0 \times 10^{12}$ & $2.4 \times 10^{11}$ \\
\hline Sb-125 & $8.7 \times 10^{14}$ & $1.4 \times 10^{15}$ & $1.5 \times 10^{14}$ & $2.6 \times 10^{13}$ & & \\
\hline Cs-137 & $3.5 \times 10^{17}$ & $5.9 \times 10^{17}$ & $6.3 \times 10^{16}$ & $1.1 \times 10^{16}$ & $2.0 \times 10^{15(b)}$ & $4.6 \times 10^{14(b)}$ \\
\hline Cs-134 & $6.7 \times 10^{14}$ & $1.1 \times 10^{15}$ & $1.2 \times 10^{14}$ & $2.0 \times 10^{13}$ & & \\
\hline Ce-144 & $<68 \times 10^{11}$ & $<1.1 \times 10^{12}$ & $<1.2 \times 10^{11}$ & $<2.1 \times 10^{10}$ & $<3.8 \times 10^{9}$ & $<8.8 \times 10^{8}$ \\
\hline Zr-95 & $9.5 \times 10^{10}$ & $1.6 \times 10^{11}$ & $1.7 \times 10^{10}$ & $2.9 \times 10^{9}$ & $5.4 \times 10^{8}$ & $1.2 \times 10^{8}$ \\
\hline Nb-95 & $4.5 \times 10^{10}$ & $7.4 \times 10^{10}$ & $7.8 \times 10^{9}$ & $1.4 \times 10^{8}$ & & \\
\hline Ru-106 & $<1.7 \times 10^{12}$ & $<2.8 \times 10^{12}$ & $<3.0 \times 10^{11}$ & $<5.2 \times 10^{10}$ & $<9.6 \times 10^{9}$ & $<2.2 \times 10^{9}$ \\
\hline Pm-147 & $3.3 \times 10^{14}$ & $5.5 \times 10^{14}$ & $5.7 \times 10^{13}$ & $1.0 \times 10^{13}$ & $1.9 \times 10^{12}$ & $4.3 \times 10^{11}$ \\
\hline Sr-90 & $1.9 \times 10^{14}$ & $3.2 \times 10^{14}$ & $3.2 \times 10^{13}$ & $5.6 \times 10^{12}$ & $1.0 \times 10^{12}$ & $2.4 \times 10^{11}$ \\
\hline & & & & & & \\
\hline $\begin{array}{l}\text { As } \\
=1\end{array}$ & & ure & le & & & \\
\hline
\end{tabular}


Table 5-4 (Continued)

\begin{tabular}{|c|c|c|c|c|c|c|}
\hline \multicolumn{7}{|c|}{ Sample Number ${ }^{(a)}$} \\
\hline $2 C$ & 3 & 4 & 5 & $6 A$ & $6 B$ & 7 \\
\hline $1.7 \times 10^{15}$ & $5.4 \times 10^{15}$ & $2.7 \times 10^{15}$ & $5.6 \times 10^{15}$ & $5.9 \times 10^{15}$ & $5.1 \times 10^{14}$ & $1.8 \times 10^{13}$ \\
\hline $3.7 \times 10^{12}$ & $1.1 \times 10^{13}$ & $5.7 \times 10^{12}$ & $1.2 \times 10^{13}$ & $1.2 \times 10^{13}$ & $1.1 \times 10^{12}$ & $3.8 \times 10^{10}$ \\
\hline & - & $\cdot$ & & - & - & \\
\hline $7.1 \times 10^{15(b)}$ & $2.2 \times 10^{16(b)}$ & $1.1 \times 10^{16}$ & $2.3 \times 10^{16(b)}$ & $2.4 \times 10^{16(b)}$ & $2.1 \times 10^{15(b)}$ & $7.3 \times 10^{13(b)}$ \\
\hline & - & - & - & & - & \\
\hline$<1.4 \times 10^{9}$ & $<4.2 \times 10^{10}$ & $<2.1 \times 10^{10}$ & ND & ND & $<4.1 \times 10^{9}$ & $<1.4 \times 10^{8}$ \\
\hline $1.9 \times 10^{9}$ & $5.9 \times 10^{9}$ & $3.0 \times 10^{9}$ & ND & ND & $5.7 \times 10^{8}$ & $2.0 \times 10^{7}$ \\
\hline - & & & - & - & & \\
\hline$<3.4 \times 10^{10}$ & $<1.1 \times 10^{11}$ & ND & ND & ND & $<1.0 \times 10^{10}$ & $<3.5 \times 10^{8}$ \\
\hline $6.6 \times 10^{12}$ & $2.0 \times 10^{13}$ & $1.0 \times 10^{13}$ & $2.1 \times 10^{13}$ & $2.2 \times 10^{13}$ & $2.0 \times 10^{12}$ & $6.8 \times 10^{10}$ \\
\hline $3.7 \times 10^{12}$ & $1.1 \times 10^{13}$ & $5.7 \times 10^{12}$ & $1.2 \times 10^{13}$ & $1.2 \times 10^{13}$ & $1.1 \times 10^{12}$ & $3.8 \times 10^{10}$ \\
\hline
\end{tabular}


Table 5-5

CALCULATED DEPOSITION OF SPECIES

PER SQUARE INCH OF LOOP SAMPLE $\left(\times 10^{-12}\right)$

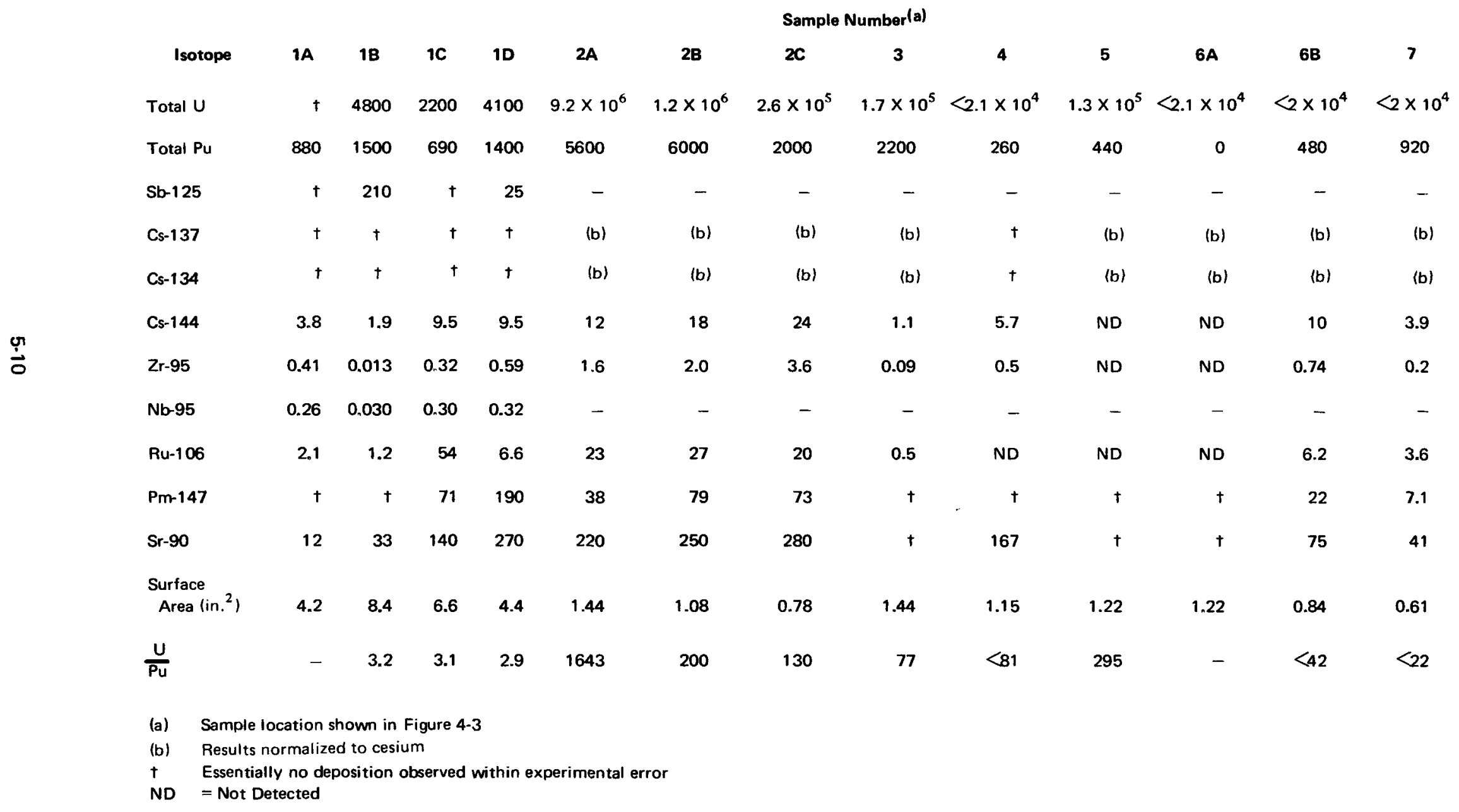




\section{ACKNOWLEDGMENTS}

The authors wish to acknowledge the assistance of the following personnel in this experimental endeavor $L L$ Moser and $\mathrm{R} \mathrm{C}$ Douglas, capsule installation and operation, E A Melaıka and R P Johnson, loop examınatıon and sample analysis

\section{REFERENCES}

1 Nelson, R C, et al, Performance of Plutonium Uranium Mixed Oxıde Fuel PIns Irradiated in a Fast Reactor (EBR II) to 50,000 MW//Te, August 1969, (GEAP 13549)

2 Murata, R E, et al, Effect of Stoichıometry on the Behavior of Mixed-Oxıde Fuel Durıng Extended Operatıon in Falled PIns, September 1971, (GEAP 13730)

3 Sodıum-Cooled Reactors Fast Ceramic Reactor Development Program, Thirty Fifth Quarterly Report, May 1970-July 1970, September 1970, (GEAP 10028 35)

4 Aitken, E A, Thermodynamic Analysis of Possible Chemical Reactions in the System $\mathrm{UO}_{2} \mathrm{PuO}_{2}$ Fuel Sodium Stainless Steel, July 1968, (GEAP 5683)

5 Gregoire, K E, et al, Faıled Fuel Performance in Naturally Convectıng Lıquıd Metal Coolant June 1970, (GEAP 13620)

6 LeipunskiI, A I, et al, Experience Gained from the Operation of the BR 5 Reactor, Paper presented at the London Conference on Fast Breeder Reactors, May 17 19, 1966

7 Brehm, W F , et al, Radiossotope Transport and Deposition in Flowing Sodıum, February 1969 (BNW/L 969)

8 Rowland, M C , et al, Sodıum Mass Transfer XIX, Long Term Exposure Effects in a Bımetallı 316 SS ? $1 / 4 \mathrm{Cr}$ Test Loop, April 1965, (GEAP 4835) 
0

0 


\section{APPENDIX. EXPERIMENT DESCRIPTION}

\section{A.1 LOOP}

The test loop consisted of the following components: electromagnetic (E.M.) pump, flowmeter, sodium sample tubes, sample exposure section (including heaters and sodium purification equipment), cooler assembly (fin tube cooler, cowling, blower, and air damper), and dump tank. A schematic diagram of the loop is shown in the preceding text (Figure 3-1 A).

Because of the high activity level of the fuel sample to be used in the test, remote operation of the loop was required. The loop was mounted inside a steel containment box which provided containment for the alpha-particle-emitting material in the loop in the event of failure during operation and also during subsequent disposal of the loop. The containment box can be seen in Figure A-1. The containment box was placed inside one of the radiation locks to the hot cells at the General Electric Radioactive Materials Laboratory. This permitted use of the interlock manipulators for remote operation of the loop. Pertinent details of the loop are described in the following paragraphs.

The sample section of the loop was provided with a hoist assembly by means of which a canister of zirconium chips was lowered into position (Figure A-2).

Only a limited quantity of heat could be dumped inside the containment box without exceeding the permissible temperature limit of the manipulators. Loop sodium flow was therefore limited to $0.1 \mathrm{gpm}$. Because of the low flow rate, a nozzle arrangement was used to obtain a more realistic sodium velocity past the cladding defect region of the test sample (for test sample details, see subsection A.2 and Figure 5-2). A system of baffles was also placed inside the finned cooler to facilitate deposition of fuel and fission products released from the fuel during the test.

All loop tubing and component parts were rinsed in acetone prior to assembly to remove any extraneous particles and grease present. Major loop components were connected to the loop tubing by means of Swagelok tube fittings. This facilitated disassembly of the loop upon completion of the test.

Loop components were preheated prior to sodium filling by means of flexible heating tape wound around the outside surfaces. The heating tape was wound in sections to permit individual temperature control of different portions of the loop. During loop operation, the heating tape was used to reduce heat loss through the loop walls, since insufficient space was available to permit the loop tubing to be heavily insulated. The cooler was preheated by means of two strip heaters placed within the cowling. The E.M. pump contained its own integral heater. Two infra-red heat lamps were placed within the containment box to provide additional heating capacity when required. Loop temperatures were monitored by means of 24 thermocouples.

The holder containing the test sample was attached to the hoist assembly by means of a snap lock device. The hoist assembly was then bolted to the top of the sample exposure section by means of a flange (O-ring seal). Leaktightness was checked by evacuating the loop and monitoring to see that no inleakage of air occurred. To further ensure no leakage of air into the loop during operation of the test, a flow of argon $(15 \mathrm{cc} / \mathrm{min})$ to the plenum region of the sample exposure section was maintained at all times during the test. Minor traces of oxygen were removed from the argon prior to the loop by passing the argon over copper turnings heated to $1200^{\circ} \mathrm{F}$. The argon was dumped from the loop to the containment box by means of a bubble jar containing mercury.

\section{A.2 TEST SAMPLE}

The test sample consisted of a 3-inch section removed from fuel pin F2U ${ }^{1}$. See Table 3-1 in preceding text for a listing of the initial fuel pin fabrication parameters.

Fuel pin F2U was irradiated in EBR-1I to 40,800 MWd/Te burnup. Figure A-3 shows the post-irradiation gross gamma scan of fuel pin F2U. Marked on the gamma scan is the location of the test sample and control sample used in the test. The fuel had been removed from the reactor for 2 years prior to the testing and contained only the longer-lived fission products.

For the test, a slot 2-3/4 inches long was cut through the cladding of the test sample, using a 0.010 -inch-thick cutting wheel. A slight springing-open of the cladding at the slot occurred so that the actual area of the slot through the cladding was $0.046 \mathrm{in.}^{2}$ (average width of opening $0.018 \mathrm{inch}$ ). In cutting the slot in the cladding, a groove $\sim 0.015$ inch deep was made in the fuel surface.

The sample holder was provided with caps which sealed the ends of the test sample. Any fuel and fission product loss from the sample was essentially limited to the defect slot by the sample holder. Figure A-4 shows the test sample mounted in the holder. 


\section{A.3 SODIUM FILL}

Prior to sodium fill, the loop components and lines were preheated to $350^{\circ} \mathrm{F}$, and the loop was evacuated. This process was continued for 4 hours to remove any acetone residue and adhering gases from the inner surfaces of the loop prior to sodium fill. Upon completion of the bake-out, the loop was back-filled with argon.

Sodium filling of the loop was accomplished by pressuring the sodium dump tank and venting the plenum region at the top of the sample test section. By monitoring the loop thermocouples, the progress of the sodium into the loop could be followed. The correct sodium fill level was obtained using a series of five thermocouples at the top of the sample exposure section.

\section{A.4 LOOP OPERATION}

After bake-out and filling of the loop with sodium, purification of the sodium was initiated. Sodium was circulated through the zirconium-chip cartridge for 20 hours at $975^{\circ} \mathrm{F}$.

Prior to introducing the test sample into the sodium, a sample of loop sodium was obtained by means of the sample tube provided (see Figure 3-1A in Section 3). This sample was to be analyzed to determine the oxygen content of the sodium at the start of the test. However, subsequent analysis of the sodium indicated that alpha contamination had occurred sometime during sodium fill or sodium purification. Since facilities available for analyzing sodium for oxygen could not handle alpha-contaminated samples at the time the experiment was conducted, no oxygen analysis was obtained.

Because of the failure of the heating tape at the plenum region of the sample test section during sodium purification, isothermal sodium temperatures in the plenum and at the entrance of the cooler could not be maintained. Therefore, fission products were free to deposit ahead of the cooler. Figure A-5 shows the temperatures maintained in various regions of the loop during operation. Refer to Table 3-2 in Section 3 for the loop operating parameters during the test. Although the test was planned to run for 100 hours, after 18 hours of operation, flow was observed to stop in the loop. Attempts to restart the flow were unsuccessful and the test was terminated. During disassembly, it was found that significant quantities of sodium had frozen on the underside of the hoist assembly in the region of the flange. The loss of the heater tape in the region of the plenum allowed the temperature at the bottom of the hoist to drop below the melting point of the sodium and act as a condenser, thus removing sodium from the circulating inventory. The loss of sodium flow in the loop was attributed to the sodium level's dropping below the outlet tube at the top of the sample exposure section.

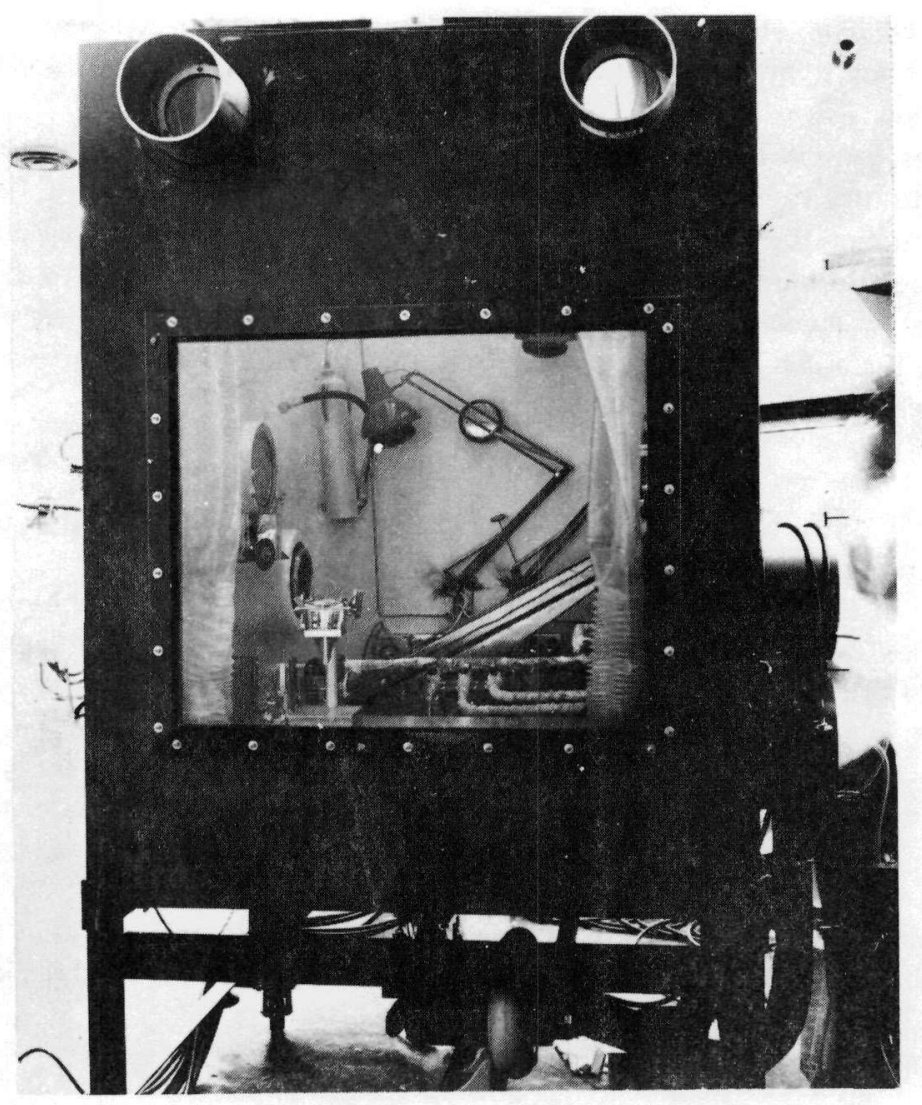

Figure A-1. Loop Containment Box 


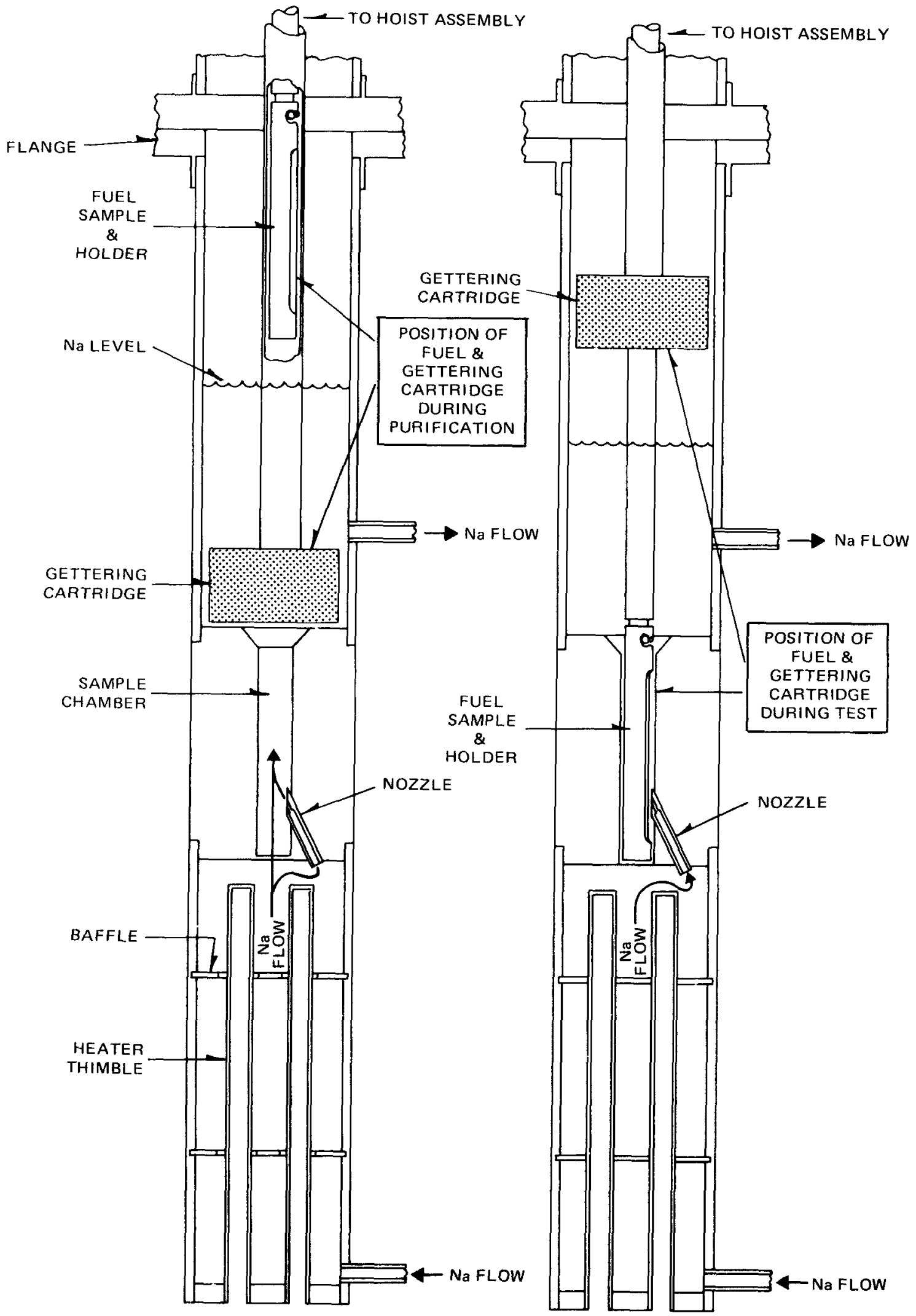

Figure A-2. Positioning of Gettering Cartridge and Fuel Sample During Sodium Purification and Test 


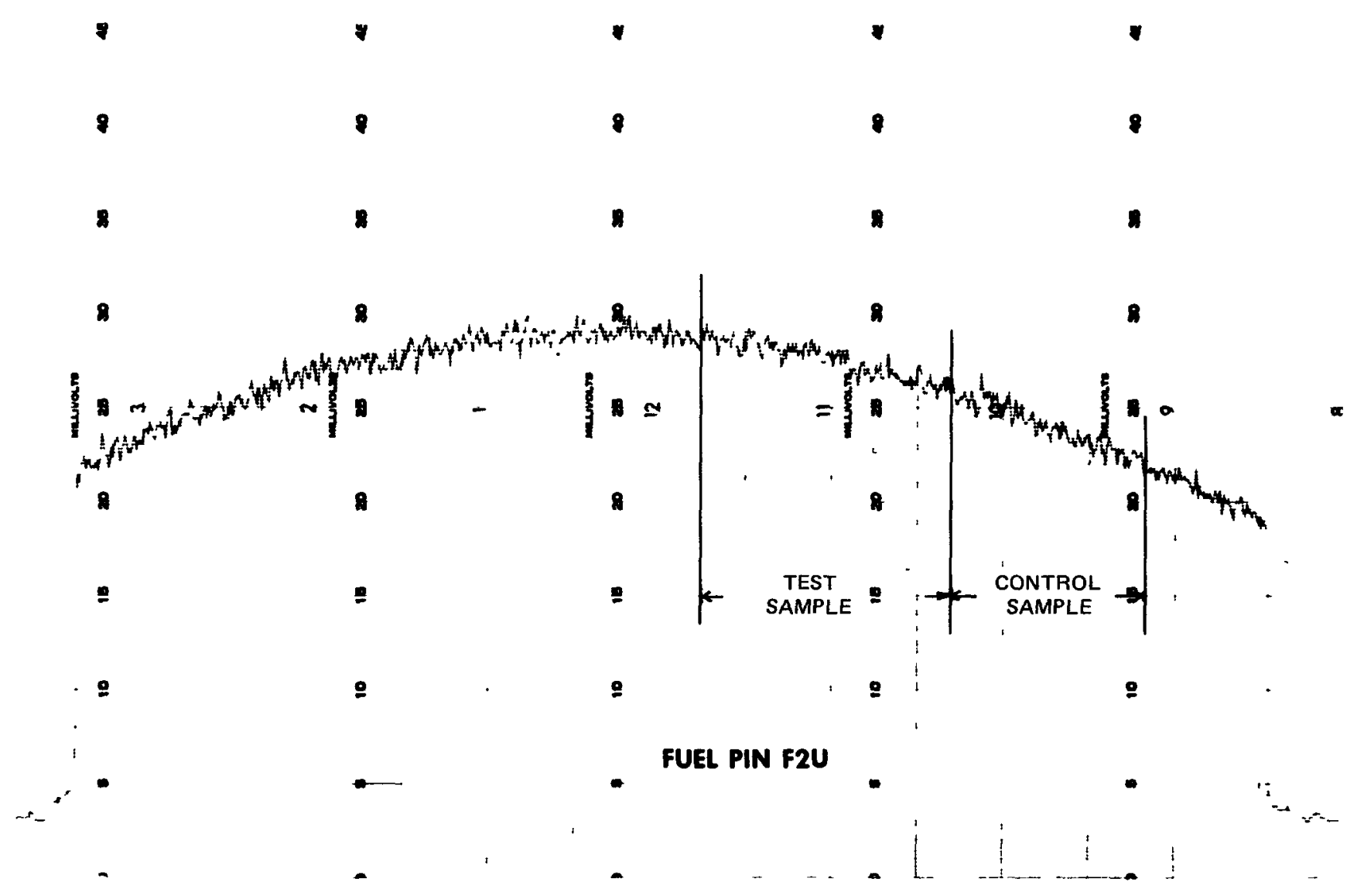

Figure A-3. Gross Gamma Scan of Fuel Pin F2U Showing Location of Test and Control Samples 

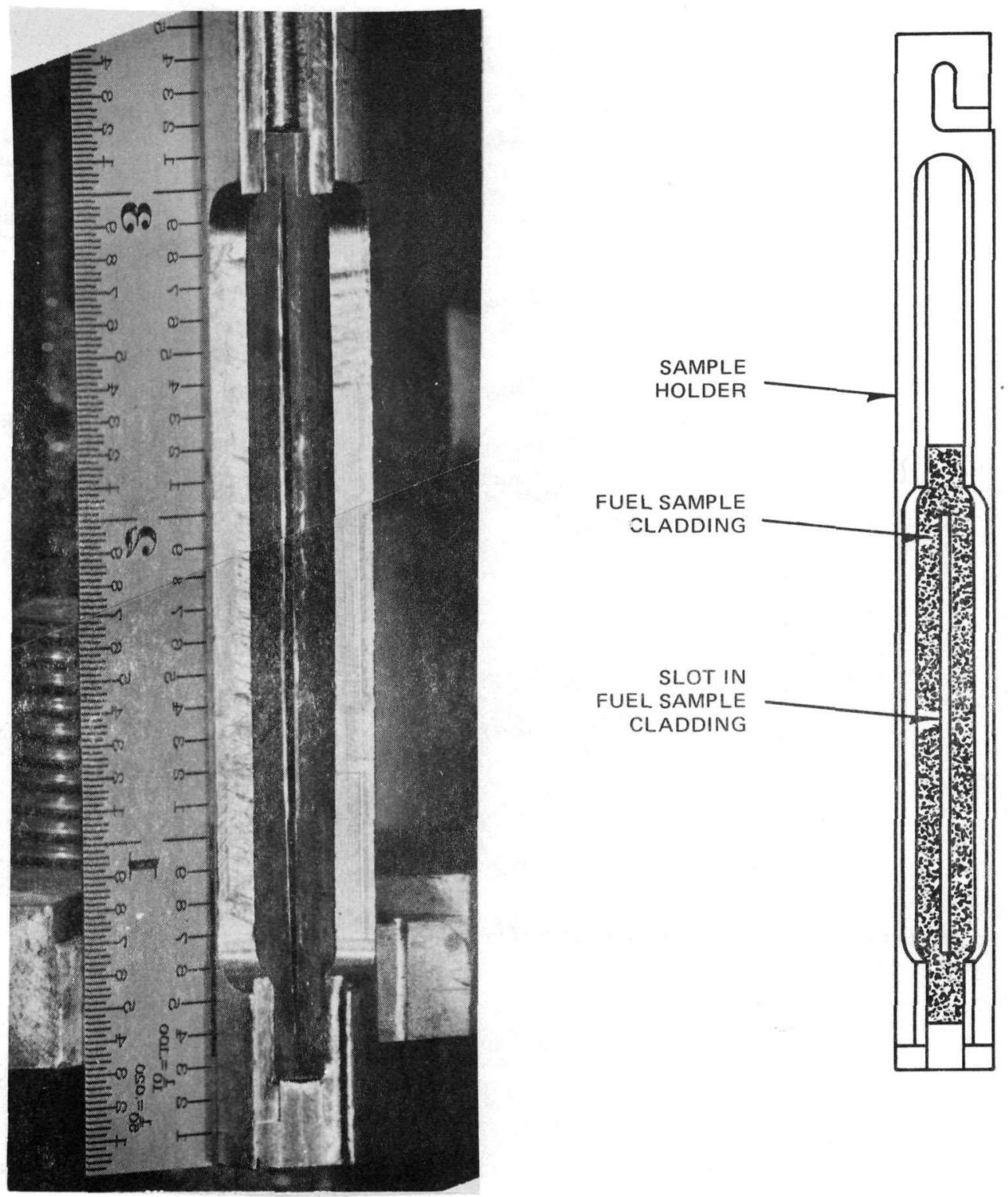

Figure A-4. Test Sample Mounted in Sample Holder 


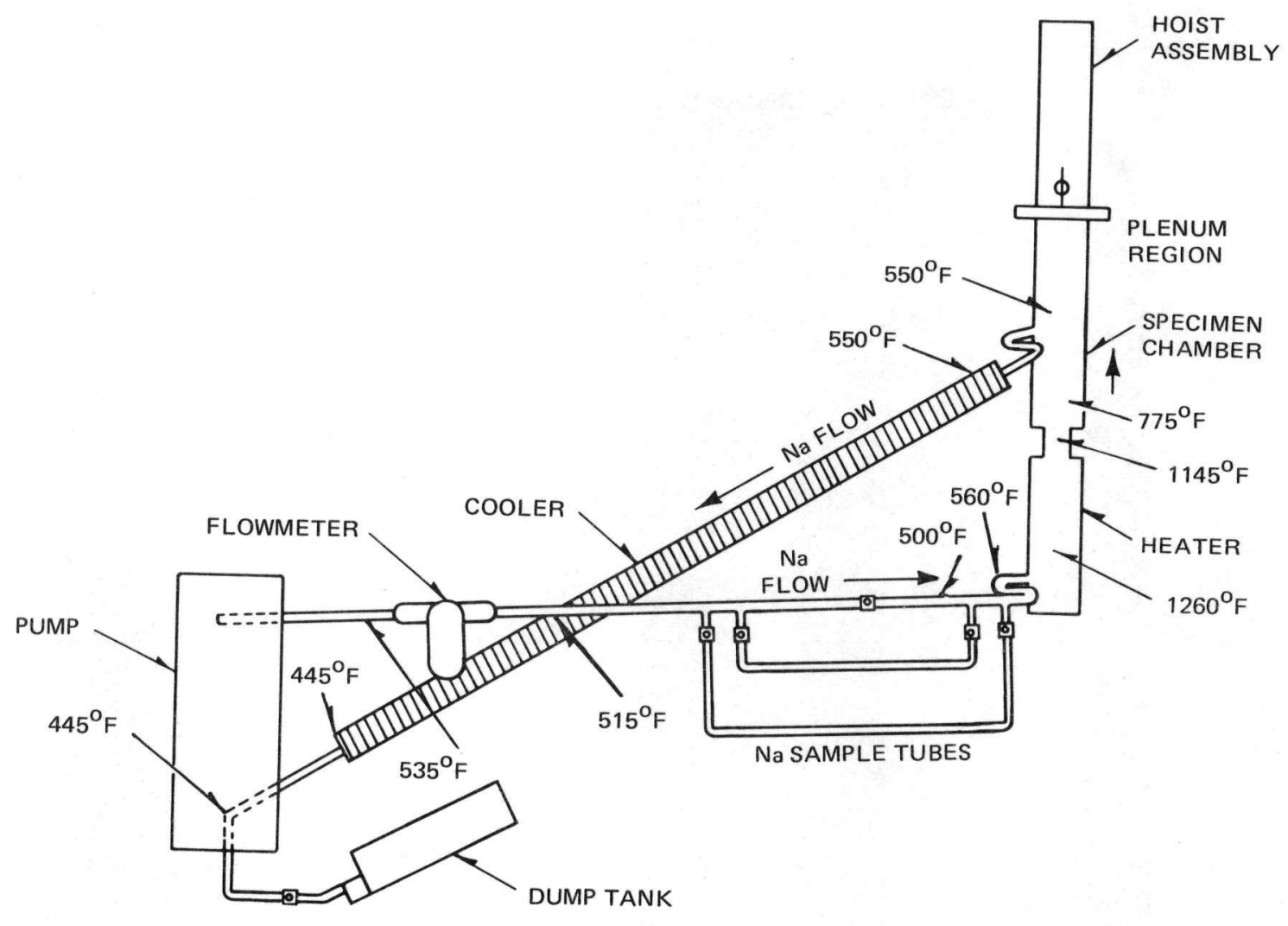

Figure A-5. Temperatures Maintained in Various Regions of Loop During Operation 


\section{DISTRIBUTION}

Director, Contracts Division U. S. Atomic Energy Commission San Francisco Operations Office 2111 Bancroft Way

Berkeley, California 94704

RDT Site Office

U. S. Atomic Energy Commission

General Electric Company

310 DeGuigne Drive

Sunnyvale, California 94086

Chief, California Patent Group

U. S. Atomic Energy Commission

San Francisco Operations Office

P. O. Box 808

Livermore, California 94550

Manager

Westinghouse Electric Corporation

Advanced Reactors Division

P. O. Box 158

Madison, Pennsylvania 15663

Division of Reactor Development and Technology, Headquarters

U. S. Atomic Energy Commission

Washington, D. C. 20545

Attn: Assistant Director.

Engineering Standards

Division of Reactor Development and Technology, Headquarters

U. S. Atomic Energy Commission

Washington, D. C. 20545

Attn: Assistant Director. Nuclear Safety

Division of Reactor Development and Technology, Headquarters U. S. Atomic Energy Commission Washington, D. C. 20545

Attn: Assistant Director,

Plant Engineering

Division of Reactor Development and Technology, Headquarters

U. S. Atomic Energy Commission Washington, D. C. 20545

Attn: Assistant Director,

Program Analysis
1 Division of Reactor Development and Technology, Headquarters U. S. Atomic Energy Commission Washington, D. C. 20545

Attn: Assistant Director,

Project Management

1

Division of Reactor Development and Technology, Headquarters

U. S. Atomic Energy Commission Washington, D. C. 20545

Attn: Assistant Director,

Reactor Engineering

1

Division of Reactor Development and Technology, Headquarters U. S. Atomic Energy Commission Washington, D. C. 20545

Attn: Assistant Director,

Reactor Technology

Division of Reactor Development and Technology, Headquarters U. S. Atomic Energy Commission Washington, D. C. 20545

1

Attn: Chief, Fuels and

Materials Branch

Division of Reactor Development and Technology, Headquarters U. S. Atomic Energy Commission Washington, D. C. 20545

Attn: Chief, Fuel Engineering Branch

Division of Reactor Development and Technology, Headquarters U. S. Atomic Energy Commission Washington, D. C. 20545

Attn: Chief, Reactor Vessels Branch

Assistant Director for Pacific Northwest Programs, RDT U. S. Atomic Energy Commission P. O. Box 550

Richland, Washington 99352

RDT Site Office

U. S. Atomic Energy Commission

Argonne National Laboratory

Building 2,

Argonne, Illinois 60439 
RDT Senior Site Representative U. S. Atomic Energy Commission P. O. Box 2325

San Diego, California 92112

Division of Naval Reactors

Chief, Nuclear Materials Branch U. S. Atomic Energy Commission Washington, D. C. 20545

Director

Division of Reactor Licensing

U. S. Atomic Energy Commission

Washington, D. C. 20545

Director

Mettalurgy Division

Argonne National Laboratory

9700 South Cass Avenue

Argonne, lllinois 60439

Manager, FFTF Project

Pacific Northwest Laboratory

P. O. Box 999

Richland, Washington 99352

Manager

Chemistry and Metallurgy Division

Pacific Northwest Laboratory

P. O. Box 999

Richland, Washington 99352

RDT Site Office

U. S. Atomic Energy Commission

Oak Ridge National Laboratory

P. O. Box X

Oak Ridge, Tennessee 37830

Director

Division of Reactor Standards

U.S. Atomic Energy Commission

Washington, D. C. 20545

Division of Technical

Information Extension

U. S. Atomic Energy Commission

P. O. Box 62

Oak Ridge, Tennessee 37831

Director

LMFBR Program Office

Argonne National Laboratory

9700 South Cass Avenue

Argonne, Illinois 60439
1 Director

Chemical Engineering Division

Argonne National Laboratory

9700 South Cass Avenue

Argonne, Illinois 60439

1

FFTF Fuels Department

Pacific Northwest Laboratory

P. O. Box 999

Richland, Washington 99352

3

RDT Site Office

U.S. Atomic Energy Commission

Atomics International

2

P. O. Box 1446

Canoga Park, California 91304

RDT Site Office

1

U.S. Atomic Energy Commission

Argonne National Laboratory

$6 \quad$ P. O. Box 2108

Idaho Falls, Idaho 83401

Division Leader (CMB)

1

1 Chemistry and Metallurgy Division

Los Alamos Scientific Laboratory

P. O. Box 1663

Los Alamos, New Mexico 87544

Director

1

$1 \quad$ Metallurgy and Materials

Science Division

Brookhaven National Laboratory

Upton, New York 11973

Division Chief, M \& S Division

1

2 NASA - Lewis Research Center

21000 Brookpark Road

Cleveland, Ohio 44135

General Manager

1

135 Westinghouse Electric Corporation

Bettis Atomic Power Laboratory

P. O. Box 79

West Mifflin, Pennsylvania 15122

Associate Manager

1

2 Materials Engineering Department

Battelle Memorial Institute

Columbus Laboratories

505 King Avenue

Columbus, Ohio 43201 
Manager, Nuclear Laboratories

Combustion Engineering Inc.

Nuclear Division

Prospect Hill Road

Windsor, Connecticut 06095

Manager, Plutonium Chemistry and Ceramics Fuels Development

Nuclear Materials and Equipment

Corporation

Plutonium Laboratory

Leechburg, Pennsylvania 15656

Head, Fuels and Materials

Atomic Power Development Associates

1911 First Street

Detroit, Michigan 48226

Director

Metals and Ceramics Division

Oak Ridge National Laboratory

P. O. Box X

Oak Ridge, Tennessee 37830

Director, Liquid Metal

Engineering Center

Atomics International

P. O. Box 1449

Canoga Park, California 91304

Manager-Advanced Development Activity

General Electric Company

Knolls Atomic Power Laboratory

P. O. Box 1072

Schenectady, New York 12301

Director, LMFBR Technology Program

Atomics International

P. O. Box 309

Canoga Park, California 91304

Director

Nuclear Development Center

The Babcock and Wilcox Company

Atomic Energy Division

Lynchburg, Virginia 24501

Laboratory Assistant Director

Gulf General Atomic Incorporated

P. O. Box 608

San Diego, California 92112
1 Manager, Research

1

United Nuclear Corporation

Research and Engineering Center

Grasslands Road

Elmsford, New York 10523

1 Director

Nuclear Safety Program

Oak Ridge National Laboratory

P. O. Box Y

Oak Ridge, Tennessee 37830

K-2 Group Leader

1

1 Reactor Division

Los Alamos Scientific Laboratory

P. O. Box 1663

Los Alamos, New Mexico 87544

2 Westinghouse Electric Corporation

2

Technical Director

Advanced Reactors Division

P. O. Box 158

Madison, Pennsylvania 15663

1 Manager

1

Liquid Metal Information Center

Atomics International

P. O. Box 1449

Canoga Park, California 91304

1 Irradiation Coordinator

1

EBR-II Project

Argonne National Laboratory

P. O. Box 2528

Idaho Falls, Idaho 83401

Experiment Manager

1

\& EBR-II Project

Argonne National Laboratory

9700 South Cass Avenue

Argonne, Illinois 60439

9

Director

9

Reactor Safety \& Analysis Division

Argonne National Laboratory

9700 South Cass Avenue

Argonne, Illinois, 60439

1 Technical Director, FFTF Project

1 
U.S. Atomic Energy Commission

Region 11 - Division of Compliance

Suite 818

230 Peach Tree Street, N. W.

Atlanta, Georgia 30303

Dr. Knox M. Broom, Jr.

Nuclear Specialist

Middle South Services, Inc.

P.O. Box 61000

New Orleans, La.
1 Assistant Director of Pacific Northwest Programs, RDT U.S. Atomic Energy Commission

P.O. Box 550

Richland, Washington 99352

1

Technical Director, FFTF Project P.O. Box 1970

Richland, Washington 99352

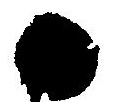

